\title{
A new genus and species of spionid polychaete (Annelida, Spionidae) from a deep- water cold seep site in the Eastern Mediterranean Sea off Turkey
}

\author{
JAMES A BLAKE ${ }^{1} \&$ PATRICIA A. RAMEY-BALCI ${ }^{2}$ \\ ${ }^{1}$ Aquatic Research \& Consulting, 24 Hitty Tom Road, Duxbury, Massachusetts, 02332 USA. \\ "Jablake9@gmail.com, (1) https://orcid.org/0000-0001-8217-9769 \\ ${ }^{2}$ College of Sciences, Koç University, Rumelifeneri Yolu 34450, Sartyer, Istanbul, Turkey. \\ ”"rameybalci@gmail.com, 이 https://orcid.org/0000-0002-5224-8863
}

\begin{abstract}
A new spionid polychaete was discovered in deep-sea sediments in the eastern Mediterranean Sea during an expedition by the Ocean Exploration Trust. Specimens were collected by the E/V Nautilus in August 2012 off Turkey, at a depth of $2216 \mathrm{~m}$ on the Anaximander Seamount at the Amsterdam mud volcano site. Cores were taken from sediments covered with microbial mats. The new species belongs to the Pygospiopsis-Atherospio Group, which has unusual neuropodial hooks, modified neurosetae in some anterior setigers, and branchiae in middle body segments that are broad, flattened, and fused to the dorsal lamellae. The new species is assigned to a new genus and species, Aciculaspio anaximanderi $\mathbf{n}$. gen., n. sp., and is unusual in having a reduced setiger 1 lacking notosetae; well-developed pre- and postsetal lamellae that encompass the neurosetae and notosetae; notopodial lamellae free from the branchiae in anterior setigers that become fused and flattened in middle and posterior segments; unidentate hooded hooks in both noto- and neuropodia; neuropodial spines in setigers 4-10; and a pygidium with three anal cirri. Aciculaspio anaximanderi n. gen., n. sp. is the first species in the Atherospio-Pygospiopsis Group collected from a deep-water cold seep habitat.
\end{abstract}

Key words: Annelida, new species, deep-sea, cold seep; mud volcano, Anaximander Seamount

\section{Introduction}

The specimens on which this study is based were collected as part of a survey conducted by the Ocean Exploration Trust (OET) of the deep-water Anaximander Seamounts in the eastern Mediterranean Sea south of Turkey (Fig. 1) of which the second author participated. The survey was conducted on the E/V Nautilus, the exploration vessel of the OET. Video obtained at the Amsterdam mud volcano site revealed active cold seeps and sediment covered with microbial mats. The ROV Hercules was used to collect benthic core samples from the microbial-mat-covered sediments which were processed for macrofauna. The sediments were found to be dominated by two different species of spionid polychaetes: Prionospio tripinnata Maciolek, 1985 and a new spionid species that is assigned to a new genus.

The new species belongs to a group of eight species of Spionidae that are currently assigned to the genera Pygospiopsis Blake, 1983 (6 species) and Atherospio Mackie \& Duff, 1986 (2 species). These taxa were recently reviewed by Blake \& Maciolek (2018) who redefined the two closely related genera and described three new species of Pygospiopsis.

The new species from the Anaximander Seamounts is similar to species of Pygospiopsis and Atherospio in having a bilobed prostomium, similar nuchal organs, anterior branchiae that are simple and free from the notopodia when they are present and posterior branchiae that are broad and fused to the notopodia. The new species, however, differs from these genera in having a reduced setiger 1 lacking notosetae; well-developed pre- and postsetal lamellae that encompass the neurosetae and notosetae; broad posterior branchiae from setiger 10 instead of 7; unusual unidentate hooded hooks in both noto- and neuropodia; modified neuropodial spines in setigers 4-10; and a pygidium that bears an elongate dorsal cirrus and two long lateral cirri. These characters distinguish the new species from each species of the two known genera. Thus, we herein describe a new genus 
and species Aciculaspio anaximanderi n. gen., n. sp., which is the first species in the Atherospio-Pygospiopsis Group to be associated with a deep-sea cold seep habitat.

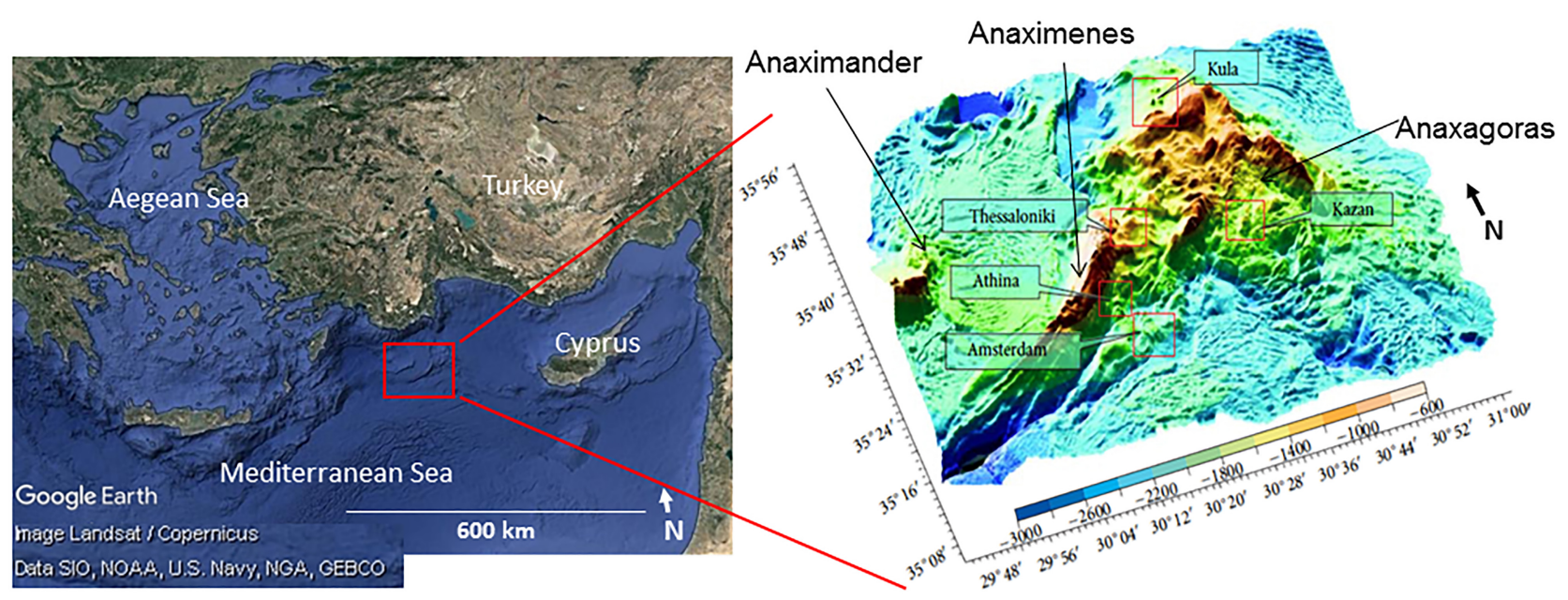

FIGURE 1. Map showing location of the Anaximander Mountains and Amsterdam mud volcano site in relation to the overall location in the eastern Mediterranean Sea. Modified from Lykousis et al. 2009 and Perissoratis et al. 2011.

\section{Materials and methods}

Push core samples (6 $\mathrm{cm}$ diameter; $28 \mathrm{~cm}^{2}$ ) were collected with the ROV Hercules. Five replicate cores were collected from the Amsterdam slope site (type locality): one for molecular barcoding, one for sediment analysis (i.e., TOC, grain size), and three for macrofauna analysis. For macrofauna, the top $5 \mathrm{~cm}$ of sediment was fixed in $4 \%$ buffered formalin and later sieved over a 500- $\mu \mathrm{m}$-mesh screen and transferred to $70 \%$ ethanol $(\mathrm{ETOH})$ with Rose Bengal. Organisms were subsequently sorted to higher taxonomic categories and identified to species where possible. Samples for grain size and TOC analyses were from the upper $6 \mathrm{~cm}$ of the respective core. Samples intended for barcoding were preserved in $90 \%$ ETOH for later analysis, but have not been processed to date.

Specimens provided for systematic study were examined and identified using stereomicroscopes and research quality compound microscopes. Photomicrographs were taken with a Nikon D7100 camera mounted on both the stereo- and compound microscopes. Some specimens were stained with a solution of Shirlastain A in water to highlight difficult-to-see surficial morphology. Methyl Green (MG) stain saturated in 70\% ETOH was used to elucidate distinct staining patterns. Both stains dissipate completely in clean ETOH. Measurements were taken with a calibrated micrometer when specimens were observed on the compound microscope under a coverslip. Line drawings were created in pencil using a drawing tube or camera lucida on the compound microscope and later transferred to Mylar and inked. Plates were prepared and edited using Microsoft PowerPoint, Adobe Acrobat, and Adobe Photoshop software.

Specimens were prepared for scanning electron microscopy (SEM) by first dehydrating in a graded ethanol series (20 mins in each of 70, 80, 90 and 100\%), and then subsequently immersing the dehydrated specimens in $3 \mathrm{ml}$ of hexamethyldisilazane (HMDS) for $10 \mathrm{mins}$ (conducted twice) to remove the ethanol. Using a pipet, the remaining HMDS was removed from the vial and the specimen was left in a desiccator to air dry at room temperature for 18 hrs (modified from Murtey \& Ramasamy 2016). Dried specimens were then mounted on aluminum stubs and sputter-coated with gold. Specimens were observed using a Carl Zeiss Ultra Plus Field Emission Scanning Electron Microscope (FEGSEM) at Koç University Surface Science and Technology Center, Istanbul, Turkey (KUYTAM).

The holotype and two paratypes are deposited in the Museum of Comparative Zoology, Harvard University (MCZ); additional paratypes, including some on SEM stubs are deposited in the Canadian Museum of Nature (CMN), Ottawa, Museum of Ege University Faculty of Fisheries (ESFM), Turkey, and the Senckenberg Research Institute and Natural History Museum, Frankfurt (SMF).

Abbreviations used on figures: anC; anal cirrus; br, branchiae; car, caruncle; pa, palp; per, peristomium; 
pr, prostomium; prL, prostomial lobe; preSL, presetal lamella; pstSL, postsetal lamella; mo, mouth; Set, setiger; sP, sensory pit; $\mathrm{vR}$, ventral ridge.

\section{Taxonomic Account}

\section{Family Spionidae Grube, 1850}

Genus Aciculaspio new genus

urn:Isid:zoobank.org:act:9E3D38B6-77DE-4161-B469-43AA8FDF9BC4

Type-species: Aciculaspio anaximanderi new species

Diagnosis. Prostomium reduced, short, about as long as wide, curved ventrally, with two spherical anterior lobes; posteriorly with short caruncle; occipital antenna absent. Branchiae from setiger 2 continuing on subsequent segments; branchiae of setigers 2-9 simple, free from dorsal lamellae; following branchiae from setiger 10 to end of body broad, membranous, fused basally to dorsal lamellae, laterally expanded. Setiger 1 reduced, lacking notosetae; subsequent parapodia biramous with well-developed pre- and postsetal lamellae surrounding setal fascicles. Alimbate, mostly hirsute, capillaries in noto- and neuropodia. Setigers 4-9 with modified neuroacicular aristate spines each covered with numerous protruding fibrils (in SEM). Unidentate hooded hooks present in noto- and neuropodia; each narrowing to curved tip or fang. Neuropodial sabre setae absent. Pygidium with one dorsal and two lateral cirri.

Etymology. The new genus name is derived from acicula, Latin for pin or needle referring to the prominent anterior neuropodial spines and Spio, Latin for sea nymph. The gender is feminine.

Remarks. Aciculaspio n. gen. is closely related to Pygospiopsis Blake, 1983 and Atherospio Mackie \& Duff, 1986. The latter two genera include eight species: Pygospiopsis (6) and Atherospio (2) and form a distinct species group within the Spionidae (Blake \& Arnofsky, 1999; Blake \& Maciolek 2018). All of the currently known species have enlarged flattened branchiae from setiger 7 that are fused to the notopodial lamellae and bear lateral ciliated extensions. Aciculaspio n. gen. has the flattened branchiae fused to the dorsal lamellae from setiger 10 instead of 7. The new genus is similar to Pygospiopsis in having additional branchiae on segments anterior to the flattened branchiae that are simple and not fused to the dorsal lamellae and to Atherospio in having prominent acicular spines in some anterior neuropodia. Aciculaspio $\mathbf{n}$. gen. differs markedly from both Pygospiopsis and Atherospio in having hooded hooks that are simple, unidentate, and have a curved and pointed fang. In contrast, species of both Pygospiopsis and Atherospio have unusual hooded hooks where the shaft terminates in a narrow tip and an apical tooth or knob is typically present on the concave side of the shaft. The hooks of Aciculaspio n. gen. resemble more typical spionid hooded hooks except that apical teeth are absent. The first setiger of Aciculaspio n. gen. is reduced shifted anteriorly and lacks notosetae. In addition, Aciculaspio n. gen. has both pre- and post setal lamellae that encompass the setal fascicles. Presetal lamellae are not common in spionids, and only occur in a few species of Prionospio and Laonice (Blake et al. 2020).

Alternatives to naming a new genus would result in either combining the new species and all species of Pygospiopsis and Atherospio into a single genus or placing the new species into one of the two known genera, probably Atherospio, which would shift the definition closer to Pygospiopsis. Although the eight previously known species and Aciculaspio anaximanderi n. gen., n. sp. appear to form a monophyletic group of species, the unusual hooded hooks in both noto- and neuropodia, the reduced nature of setiger 1, including lack of notosetae, the presence of both pre- and postsetal fleshy lamellae surrounding the setal fascicles, and morphology and large number of the neuropodial spines of the new species justify a separate genus.

\section{Aciculaspio anaximanderi new species}

Figures 2-5

urn:1sid:zoobank.org:act:1C040CFC-7793-4624-8030-1B6B43302F44

Material examined. Mediterranean Sea, off Turkey, south of Anatyla, subsea Anaximander Seamounts, 
on the slope of Amsterdam mud volcano, E/V Nautilus Cruise No. NA022-008, ROV Hercules Dive No. H1230, 28 Jul 2012, 35 $18.540309^{\prime} \mathrm{N}, 30^{\circ} 16.520486^{\prime} \mathrm{E}, 0-5 \mathrm{~cm}$ of core, Replicate C, $2216 \mathrm{~m}$, holotype (MCZ 153556), 2 paratypes (MCZ 153557), 2 paratypes (CMNA 2019-0106), 1 paratype on SEM stub (CMNA 2017), 1 paratype (ESFM-POL/2012-498), 1 paratype on SEM stub (SMF 27775: SEM-stub 1312).

Description. Holotype $6.3 \mathrm{~mm}$ long, $0.51 \mathrm{~mm}$ wide, with 65 setigers; paratypes with 44-68 setigers. Dorsal surface of anterior 9-10 segments relatively smooth and rounded (Figs. 2A, 4A); following segments with dorsum obscured by overlapping broad branchiae and notopodial lamellae (Fig. 4A). Venter flattened with low mid-ventral ridge along entire body (Fig. 4E). Color in alcohol white; anterior neuropodial spines appearing golden against white background (Fig. 3C, arrows).

Prostomium with anterior border curved ventrally toward anterior lip of mouth, with two separate spherical lobes on anterior margin, best seen ventrally (Figs. 2A-B, 3A-B, 4B-C), these often not visible dorsally due to ventral curvature of prostomium. A short caruncle extends posteriorly between notopodia of setiger 1 (Figs. 2A, 4C); occipital antenna not observed, but some specimens with small oval depression visible possibly representing scar of lost antenna or sensory pit (Fig. 4C). Eyes absent; nuchal organs transverse slits lateral to posterior margin of caruncle (Fig. 4C, arrow). Peristomium reduced, forming anterior and posterior lips of mouth; anterior lip with three lobes, posterior lip broad, curved (Figs. 2B, 3A-B). Palps short, thick, curved, with a deep ventral groove (Figs. 2A-B, 3A-B, 4B).

Setiger 1 reduced, shifted anteriorly lateral to prostomium (Figs. 2A-B, 4B-C) with neuropodia having a relatively prominent postsetal lamella; notopodia reduced to a short lobe entirely lacking notosetae. Branchiae from setiger 2 continuing to posterior end (Figs. 2A, C, 4A, B); branchiae of setigers 2-9 cirriform, free from dorsal lamellae (Figs. 2A, 4B, F); branchiae from setiger 10 basally fused to dorsal lamellae, with broad lateral extensions or membranes developing along individual branchia about half-way along their length (Fig. 2A).

Noto- and neuropodia with well-developed fleshy pre- and postsetal lamellae surrounding setal fascicles (Figs. 4E, 5E), best developed from about setiger 9-10. Setae include noto- and neuropodial capillaries, modified anterior neuropodial spines, and hooded unidentate hooks in noto- and neuropodia. Modified neurosetae of setigers 4-10 heavy thick brown pointed spines (Figs. 2D-G, 3C-D, 5A-D); spines of setigers 5-8 heaviest, numbering 4-5 per fascicle; spines of setigers 4, 9-10 smaller, transitional. All modified neurosetae arranged in a curved row; each spine with prominent thickened emergent fibrils or bristles and tapering to apical arista (Figs. 2F-G, 3D, 5A-D); bristles appearing as fringe extending out and onto arista; some spines with arista worn away, with tip rounded instead of pointed (Fig. 2D-E). Second row of 7-10 thin bristled capillaries posterior to spines (Fig. 5B-D). Anterior notosetae all capillaries, with two kinds present in anterior 5-10 setigers; setae arranged in 2-3 rows with those of anterior rows long, tapered; setae of last row shorter, distinctly recurved; capillaries generally smooth, with few bristles. Hooded hooks first present from setiger 22-25 in notopodia and setiger 14-15 in neuropodia. Hooks numbering 2-7 per fascicle accompanied by long thin smooth capillaries (Fig. 5E-F). Individual hooded hooks unidentate, with straight shafts narrowing apically to curved tooth projecting at 30-60 angle to shaft depending on orientation during observation (Fig. $2 \mathrm{H}-\mathrm{I}$ ); hood transparent in light microscopy, covering end of shaft and curved tip (Fig. 2H-I); with SEM, hood observed with numerous fibrils obscuring curved fang (Fig. 5F-G).

Pygidium a rounded lobe bearing three long cirri: one mid-dorsal and two laterals (Figs. 2C, 4D).

Methyl Green stain. No pattern, body staining uniformly blue-green along entire length; destaining rapidly.

Remarks. Aciculaspio anaximanderi n. gen., n. sp. is easily recognized by the short pre-setiger region with a ventrally directed prostomium bearing a pair of spherical lobes on the anterior margin, a short caruncle and associated short thick palps; well-developed pre- and postsetal lamellae that encompass the neuro- and notosetal fascicles; branchiae that are fused with the notopodial lamellae from setiger 10 and develop broad membranous lateral extensions. Unidentate hooded hooks occur in both noto- and neuropodia; related species of Pygospiopsis and Atherospio have hooks only in the neuropodia. Modified spines in neuropodia of setigers 4-10 have a prominent bristled aristate apex. The pygidium bears three anal cirri instead of four or more that occur in related species of Pygospiopsis and Atherospio. Further details of how this new genus and species compared morphologically to species of the closely related genera Pygospiopsis and Atherospio is presented in the Discussion. 


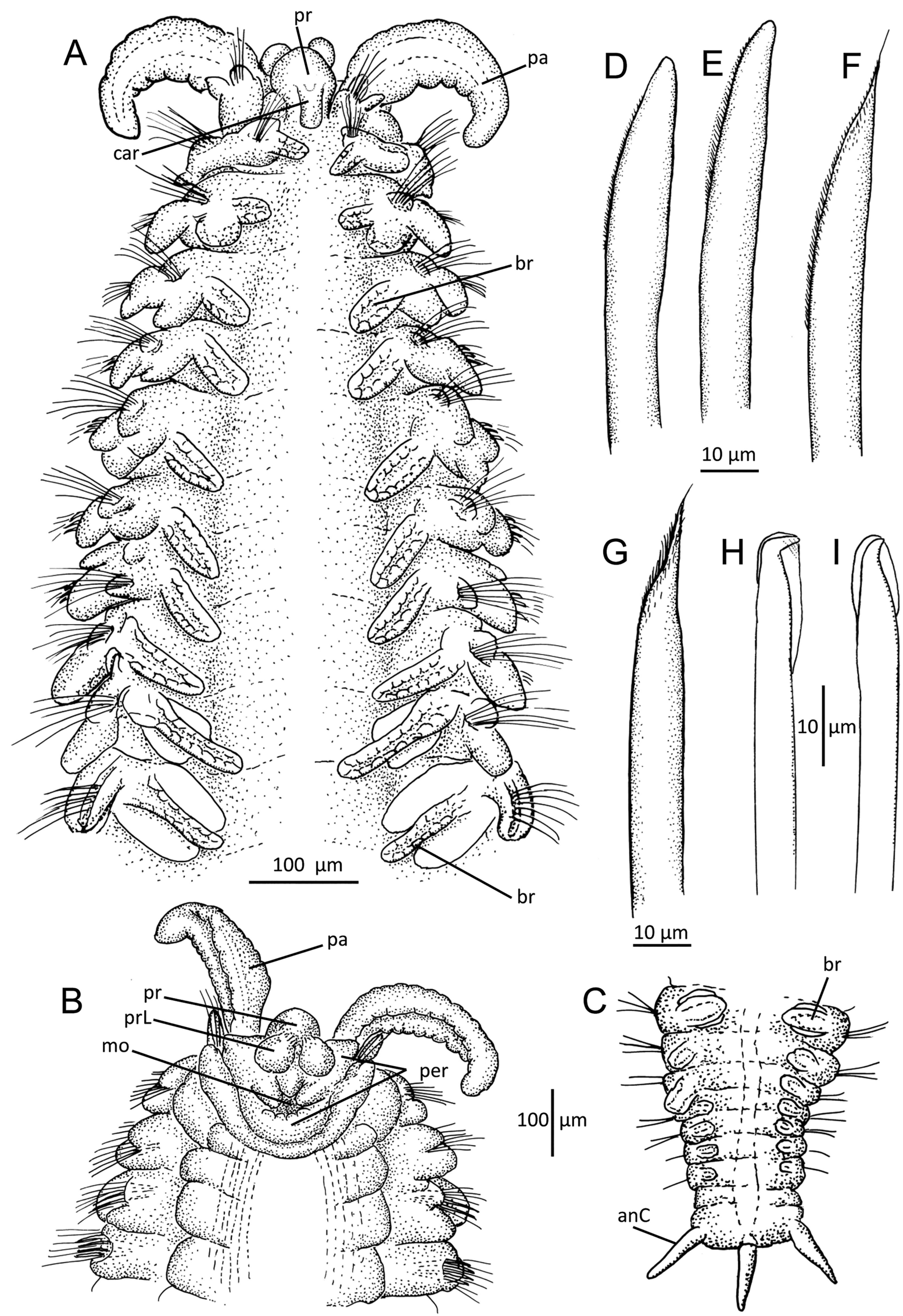

FIGURE 2. Aciculaspio anaximanderi n. gen., n. sp. Holotype (MCZ 153556). A, anterior end, dorsal view; B, anterior end, ventral view; C, posterior end, dorsal view; D-G, neuropodial acicular spines from setigers 5 and 6 showing worn (D-E) and unworn spines with apical arista (F-G); H-I, neuropodial hooded hooks. 

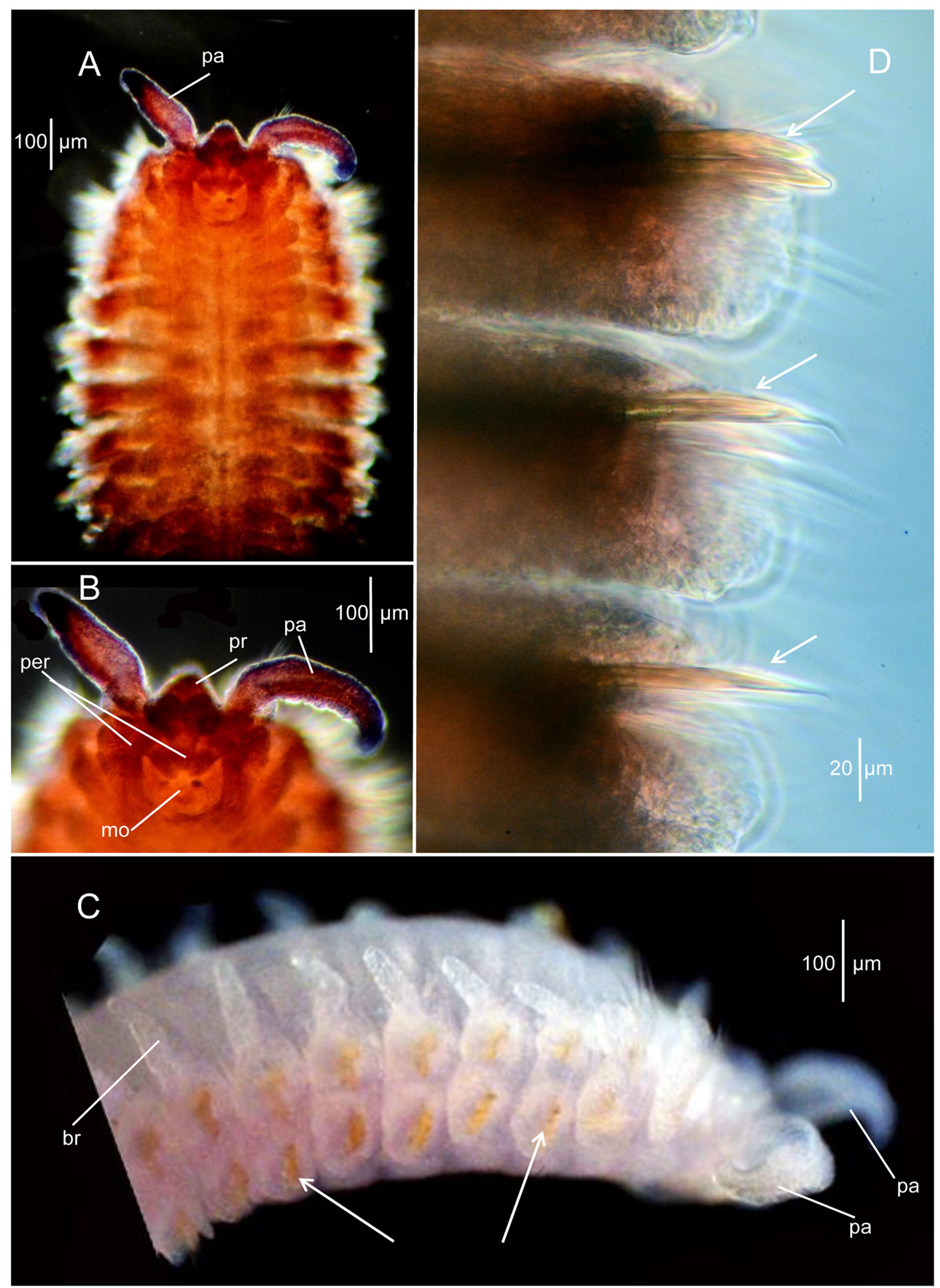

FIGURE 3. Aciculaspio anaximanderi n. gen., n. sp. Paratypes (MCZ 153557) photomicrographs. A, anterior end, ventral view showing general shape body; B, same, pre-setiger region; C, another specimen, right lateral view; D, setigers 6-8, ventral view, with modified neuropodial spines. A-B, stained with Shirlastain A. Arrows denote neuropodial spines. 

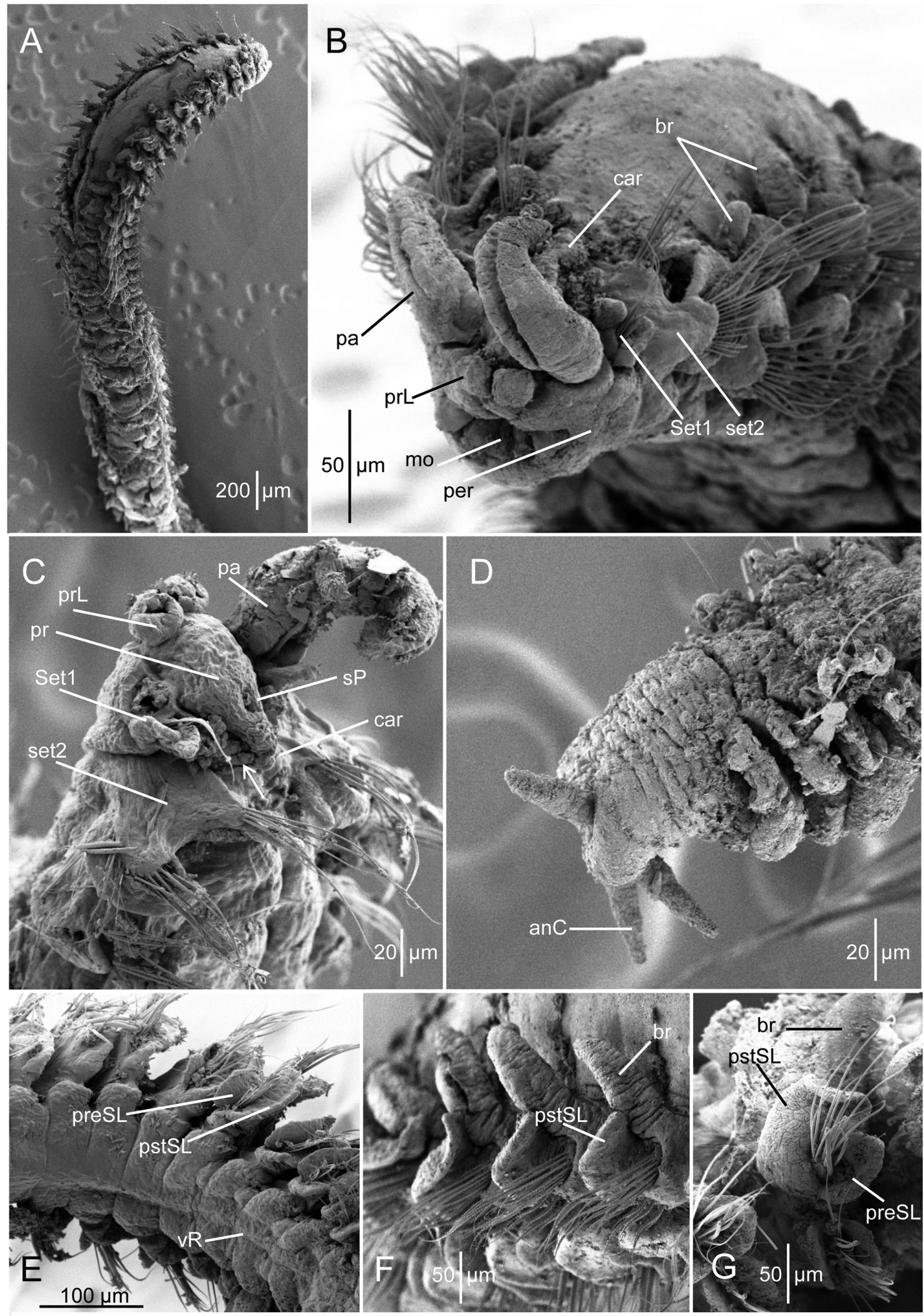

FIGURE 4. Aciculaspio anaximanderi n. gen., n. sp. Paratypes (CMNA 2019-017 A, C-E; SMF 2775: SEM stub 1321 D, F-G, SEMs. A, mostly complete worm, dorsal view; B, anterior end, frontal lateral view; C, anterior end, dorsal lateral view (arrow, nuchal organ); D, pygidium with anal cirri, dorsal lateral view; E, middle body segments, ventrolateral view, with ventral ridge and neuropodia with pre- and postsetal lamellae; F, anterior body setigers, with notopodial postsetal lamellae and digitate branchiae; frontal lateral view; G, middle body setiger, frontal view with parapodial lamellae and branchia. 


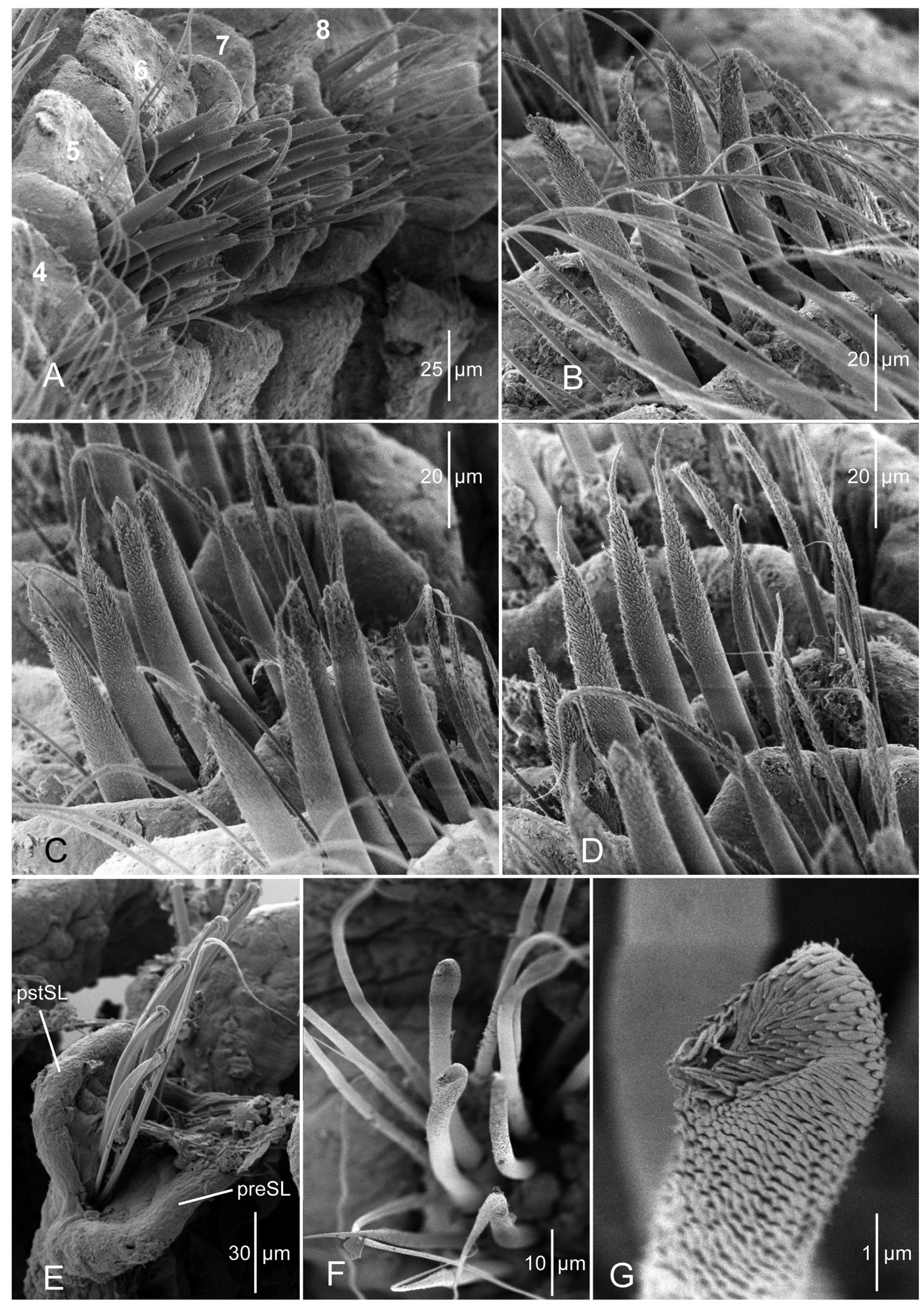

FIGURE 5. Aciculaspio anaximanderi n. gen., n. sp. Paratypes (SMF 2775: SEM-stub 1321 A-D, F-G; CMNA 20190107 E), SEMs. A, sequence of neuropodia setigers 4-8, rows of spines; B-D, neuropodial hooks from anterior setigers; E, neuropodium from mid-body setiger showing a row of hooded hooks and capillaries with pre- and postsetal lamellae; F, close up of neuropodial hooded hooks and capillaries; G, detail hood of a neuropodial hook with numerous fibrils that compose hood and obscure tooth. 
Etymology. The specific name anaximanderi is derived from both the region of its discovery, the undersea Anaximander Seamounts, and the Greek philosopher of the 6th century B.C. Anaximander (610-546 B.C.) for which the site was named. Anaximander was an early Pre-Socratic philosopher from the Greek city of Miletus in Ionia (modern-day Turkey).

Distribution. Eastern Mediterranean Sea, Anaximander Seamount, cold seeps 2216 m.

\section{Discussion}

The Anaximander Seamounts. The Anaximander Mountains are located in a complex, tectonically active area between the Hellenic subduction zone and the Cyprus arc in the eastern Mediterranean Sea, and are comprised of three seamounts: Anaximander, Anaximenes, and Anaxagoras. Local tectonic activity has resulted in the formation of seafloor features hosting diverse habitats, including mud volcanoes and cold seeps. The geology of the Anaximander Mountains has been described by Lykousis et al. (2009) and Perissoratis et al. (2011).

The E/V Nautilus expedition to five mud volcanoes (i.e., Amsterdam, Thessaloniki, Athina, Kazan, and Kula) on the Anaximander Seamounts was conducted in July-August 2012. Active seeping was evident at several mud volcanoes including Amsterdam, Thessaloniki, and Athina, where methane bubbles were observed escaping the seafloor through fractured carbonate crust (Raineault et al. 2013). These areas were host to abundant Siboglinidae tubeworm populations, Lamellibrachia anaximandri Southward, Andersen \& Hourdez, 2011. Temperature of the actively seeping fluid was the same as the ambient seawater temperature, $14^{\circ} \mathrm{C}$ (Raineault et al. 2013). Reduced sediments with and without white mats (presumably microbial) were patchily distributed at all five mud volcanoes and were one of the most commonly observed microhabitats. All samples were collected from light to dark grey reduced sediments. Aciculaspio anaximanderi $\mathbf{n}$. gen., $\mathbf{n}$. sp. was present at three of the five mud volcanoes sampled including Amsterdam (i.e., summit, slope and base areas), Athina, and Kazan at densities ranging from 1-20 ind. $28 \mathrm{~cm}^{-2}$. Fifty-five specimens were collected with the large majority occurring at the Amsterdam mud volcano (52/55 specimens $=95 \%)$ with $69 \%$ of these $(36 / 52$ specimens) at the Amsterdam slope type locality.

Habitat and ecology at the type-locality (Figure 6). The type locality of Aciculaspio anaximanderi $\mathbf{n} . \mathbf{s p}$. is located at a depth of $2216 \mathrm{~m}$ on the slope of the Amsterdam mud volcano (Fig. 6B). The area is characterized by the presence of carbonate crust, shell hash (bivalve shells scattered on the surface), reduced grey colored sediments interspersed with beige non-reduced/oxygenated hemipelagic sediment, and white microbial mats. Push cores were collected from reduced sediments covered with the microbial mats. Sediment was composed of sandy silt, including $28.6 \%$ sand $(0.063-2 \mathrm{~mm}), 53.8 \%$ silt $(0.002-0.063 \mathrm{~mm})$, and $17.6 \%$ clay $(<0.002$ $\mathrm{mm}$ ). Total organic carbon was $1.2 \%$. Water temperature at the collecting site was $14^{\circ} \mathrm{C}$, salinity $38.78 \mathrm{PSU}$, and oxygen $=204.9$ at $63.96 \%$ saturation.

Polychaetes were the largest component of the macrofauna (79\%) at this site; a bivalve known to contain symbiotic sulfur-oxidizing (chemosynthetic) bacteria, Isorropodon perplexum (Olu-Le Roy et al. 2004) cumaceans; gastropods (i.e., Clelandella myriamae Gofas, 2005; Skeneidae sp.); and an unidentified amphipod comprised the remaining $12 \%, 8 \%, 1 \%$ and $0.5 \%$ of the total abundance, respectively. Among the polychaetes, Aciculaspio anaximanderi $\mathbf{n}$. gen., n. sp. was the second most abundant species present $(12 \pm 9.3$ ind. $28 \mathrm{~cm}^{-2} ; n=3$ ) reaching a maximum density of 20 ind. $28 \mathrm{~cm}^{-2}$. Aciculaspio anaximanderi $\mathbf{n}$. gen., n. sp. was commonly associated with another spionid, Prionospio tripinnata, originally described from $500 \mathrm{~m}$ depth in the Mediterranean Sea (Maciolek 1985), was the most abundant species collected at the type locality (31 \pm 9.3 ind. $28 \mathrm{~cm}^{-2} ; n=3$ ). Other co-occurring polychaete species at the type locality included the ampharetid Glyphanostomum bilabiatum Reuscher \& Fiege, 2016 (density $0.7 \pm 1.2$ ind. $28 \mathrm{~cm}^{-2}$ ), which was recently described from the Yonaguni Knoll IV hydrothermal vent field, Okinawa Trough, off the coast of Taiwan at $1365 \mathrm{~m}$ (Reuscher \& Fiege 2016); a capitellid, Mediomastus sp. $\left(2 \pm 1.0\right.$ ind. $\left.\mathrm{cm}^{-2}\right)$; and an unidentified scale worm $\left(4 \pm 3.4\right.$ ind. $\left.28 \mathrm{~cm}^{-2}\right)$. Aciculaspio anaximanderi $\mathbf{n}$. gen., n. sp. was also found at the summit of Amsterdam mud volcano (Fig. 6A) in association with a dorvilleid, Ophryotrocha sp., and the bivalves Idas modiolaeformis (Sturany, 1896) which contains both sulfur and methane oxidizing bacteria (Duperron et al. 2008) and Thyasira striata likely containing sulfur oxidizing bacteria (Taviani 2014). Overall, macrofaunal taxon richness at the type locality was 10 with 187 individuals collected $\left(62 \pm 2928 \mathrm{~cm}^{-2} ; n=3\right)$. 


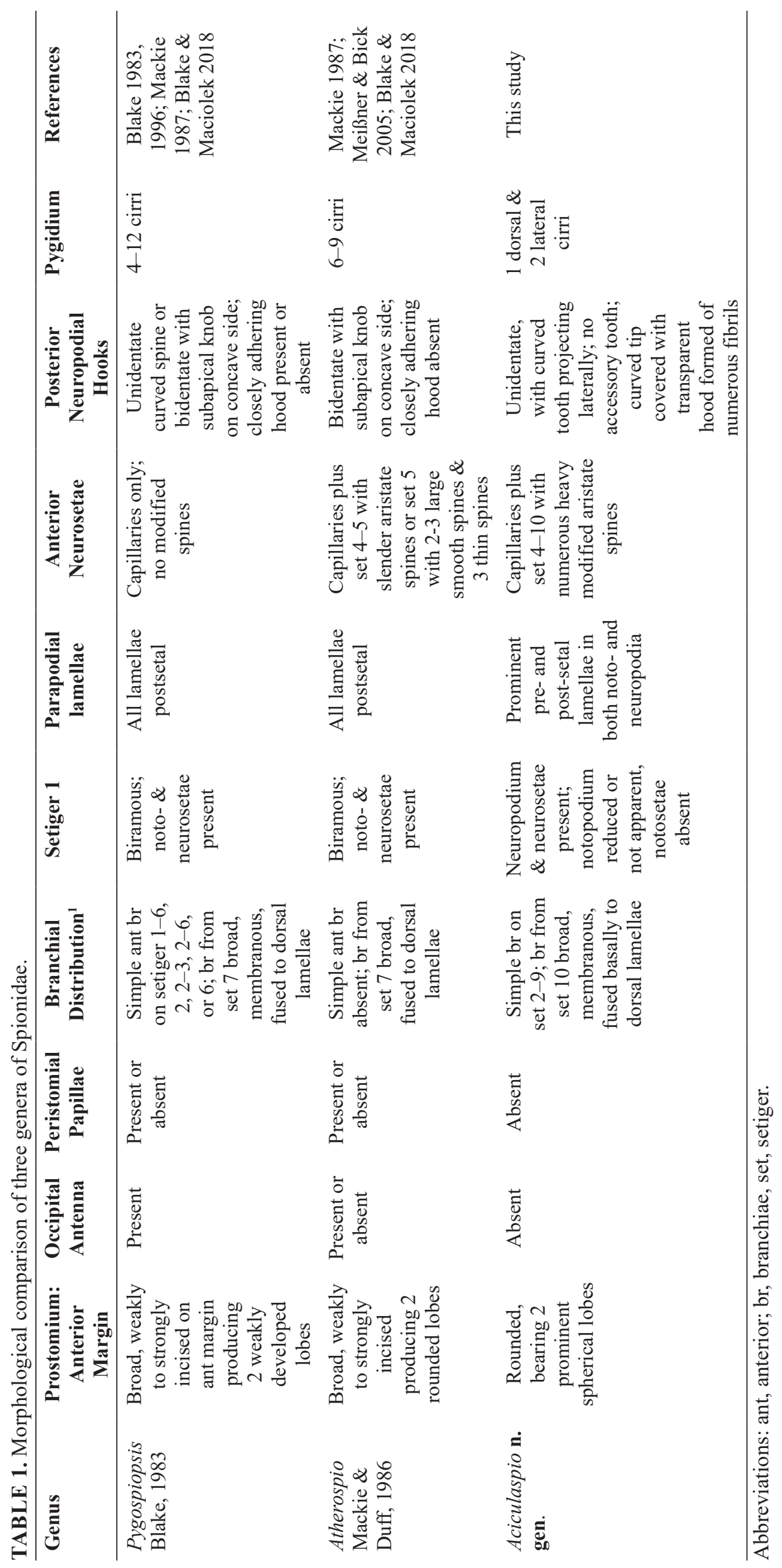



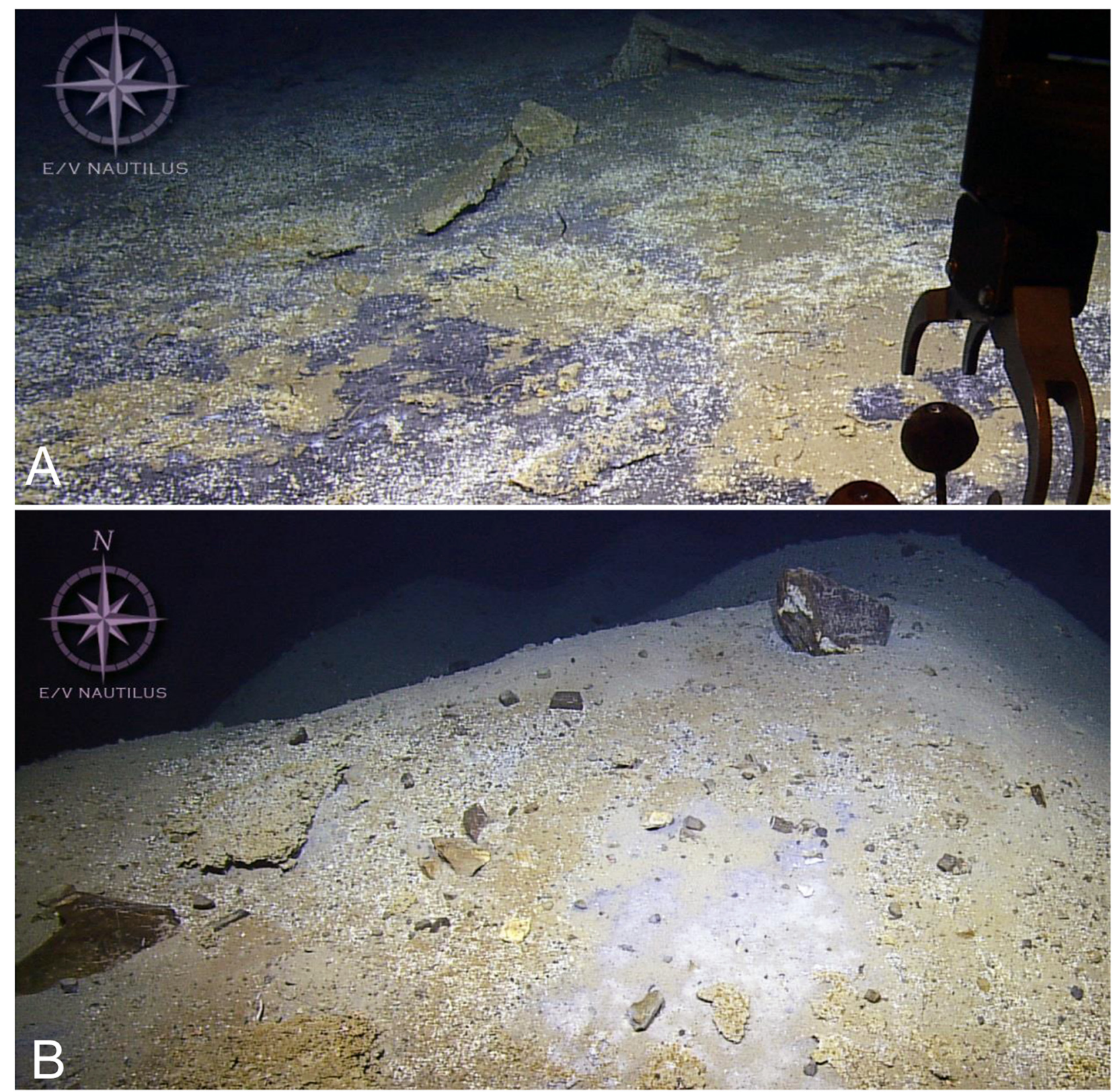

FIGURE 6. Amsterdam mud volcano. A, summit; B, slope.

Comparison of Aciculaspio n. gen. with Atherospio and Pygospiopsis (Table 1) The similarities and differences between species of Pygospiopsis and Atherospio were reviewed and tabulated in detail by Blake $\&$ Maciolek (2018). Apart from the absence of simple anterior branchiae and the presence of large modified neuropodial spines on 1-2 anterior neuropodia in Atherospio, the two genera are similar in other respects, including features of the prostomium, presence/absence of peristomial papillae, pygidium with four or more anal cirri, location of nuchal organs, and unusual neuropodial hooded hooks where the apical tooth when present is on the concave side of the shaft. Blake \& Arnofsky (1999), as part of a phylogenetic analysis of Spionidae using morphology, recovered these genera as a monophyletic clade in which close similarities with other spionids were not apparent. Specific morphological differences between Aciculaspio anaximanderi n. sp. with previously described species of Atherospio and Pygospiopsis are summarized in the following paragraphs and compared in Table 1.

Pre-setiger region. In all eight known species of Pygospiopsis and Atherospio, the prostomium is longer than wide and prominent dorsally on a well-developed peristomium. In all species except A. guillei, an occipital 
antenna is present. The anterior margin of the prostomium is incised and visible dorsally. Nuchal organs are narrow transverse slits between the posterior border of the prostomium and setiger 1. Peristomial papillae are present or absent. The palps arise lateral to the prostomium.

In Aciculaspio anaximanderi n. gen., n. sp., the prostomium is relatively short, about as long as wide and directed ventrally toward the mouth; it has two rounded lobes on the anterior margin often not visible dorsally, but clearly seen if viewed frontally or ventrally. A short caruncle is present; an occipital antenna is absent, but a depression is often visible where an antenna might be expected. Nuchal organs appear to be lateral grooves near the end of the caruncle, similar to those reported for Pygospiopsis and Atherospio. The peristomium of $A$. anaximanderi n. gen., n. sp. is reduced; it is not apparent dorsally but is well developed as dorsal and ventral lips surrounding the mouth. Due to the reduced peristomium, the palps are shifted lateral to the prostomium and anterior to setiger 1. Peristomial papillae are absent.

Setiger 1. Setiger 1 is biramous and well-developed in species of Pygospiopsis and Atherospio with notoand neuropodia and capillary setae generally similar to those of subsequent anterior segments. In Aciculaspio anaximanderi n. gen., n. sp., setiger 1 is shifted anteriorly, and has a reduced neuropodium and shorter neurosetae compared to subsequent segments; the notopodium is reduced to a simple lobe (sometimes not apparent) and notosetae are entirely absent. Setiger 1 is difficult to observe at certain angles and is obscured by the palps unless they are removed.

Parapodial lamellae. Species of Pygospiopsis and Atherospio typically have well-developed postsetal lamellae that are fused with the branchiae in middle segments. In Aciculaspio anaximanderi n. gen., n. sp., a prominent pre-setal lamella is also present; best developed from about setiger 10, and together with the postsetal lamella, surrounds each setal fascicle.

Branchiae. All species of Pygospiopsis and Atherospio have broadly flattened branchiae from setiger 7 that are fused to the notopodial postsetal lamellae. Species of Pygospiopsis also have simple digitiform branchiae on some setigers anterior to setiger 7, not fused basally, the distribution of which differ between species (Blake \& Maciolek 2018). Species of Atherospio have no branchiae anterior to setiger 7. In Aciculaspio anaximanderi $\mathbf{n}$. gen., n. sp., simple digitiform branchiae free from the dorsal lamellae are present on setigers $2-9$, followed by broadly flattened branchiae fused to the notopodial lamellae from setiger 10 and continuing to near the posterior end.

Modified anterior neurosetae. Enlarged and modified anterior neurosetae are absent in Pygospiopsis but present in Atherospio. In A. disticha Mackie \& Duff, 1986, modified aristate neurosetae occur in a double row on setigers 4-5; in A. guillei (Laubier \& Ramos, 1974), two or three heavy neuropodial spines and three thin spines occur on setiger 5. In Aciculaspio anaximanderi n. gen., n. sp., prominent modified neurosetae are present on setigers 4-10 as heavy pointed spines, each tapering to an apical arista with thickened emergent fibrils or bristles. These spines are readily visible when viewing the worms with a stereomicroscope.

Hooded hooks. The neuropodial hooks of Pygospiopsis and Atherospio are unique in that they are unhooded and have curved shafts that have a subapical tooth on the concave side of the shaft instead of on the convex side as in all other spionids. In some Pygospiopsis species, the subapical tooth is absent or worn. In Aciculaspio anaximanderi n. gen., n. sp., the neuropodial hooks are different, with the shaft narrowing apically to a curved tooth that projects laterally and lacks any extra apical teeth; a hood covers the entire end of the shaft and tooth. In SEM the hood can be seen to consist of fibrils that completely obscure the shaft and curved tip.

Pygidium. In species of Pygospiopsis and Atherospio, the pygidium, when described, has 4-12 cirri (Blake \& Maciolek 2018). In Aciculaspio anaximanderi n. gen., n. sp. the pygidium bears one mid-dorsal and two lateral anal cirri.

\section{Acknowledgements}

The authors would like to thank the crew members of the E/V Nautilus (cruise NA022), as well as the scientific and technical staff involved in the field sampling, especially Chief Scientist Nicole Raineault who also led the benthic sampling and fixed the samples during the cruise. Several undergraduate students at Koç University (Work Study Program) were involved in sorting macroinvertebrates from samples including Beyza Cimen, Cemre Ağaoğlu, Ceyda Ozler, and Selin Tanrikulu. Thanks also go to the Koç University Surface Science 
and Technology Center (KUYTAM) and Barış Yağcı for use of the SEM. Sediment analysis was conducted by M. Duman (Dokuz Eylul University, Turkey), and data provided by OET. We gratefully acknowledge the infrastructure support provided by the Ocean Exploration Trust, USA. The Ministry of Foreign Affairs of the Republic of Turkey issued scientific research and collection permits (no. 2012/DHGY/5852515). This paper was presented as a poster at the thirteenth International Polychaete Conference held in Long Beach, California (Aug 5-9, 2019). The authors thank the organizers of the Conference for an excellent meeting. A draft of the manuscript benefited from comments and editing by Dr. Nancy J. Maciolek. Comments by Drs. Vasily Radashevsky and Jason D. Williams greatly improved the manuscript and are appreciated.

\section{References}

Blake, J.A. (1983) Polychaetes of the family Spionidae from South America, Antarctica and adjacent seas and islands. Biology of Antarctic Seas XIV. In: Antarctic Research Series, 39, 205-288. https://doi.org/10.1029/AR039p0205

Blake, J.A. (1996) Chapter 4. Family Spionidae Grube, 1850, including a review of the genera and species from California and a revision of the genus Polydora Bosc, 1802. In: Blake, J.A., Hilbig, B. \& Scott, P.H. (Eds.), Taxonomic Atlas of the Santa Maria Basin and Western Santa Barbara Channel. Vol. 6. Annelida Part 3. Polychaeta: Orbiniidae to Cossuridae. Santa Barbara Museum of Natural History, Santa Barbara, pp. 81-223.

Blake, J.A. \& Arnofsky, P.L. (1999) Reproduction and larval development of the spioniform Polychaeta with application to systematics and phylogeny. Reproductive Strategies and Developmental Patterns in Annelids. Hydrobiologia, 402, 57106. https://doi.org/10.1023/A:1003784324125

Blake, J.A. \& Maciolek, N.J. (2018) New species and records of Uncispionidae and Pygospiopsis (Polychaeta, Spionidae) from deep water off the east and west coasts of North America, the Gulf of Mexico, the Antarctic Peninsula, and Southeast Asia. Zootaxa, 4450 (2), 151-195. https://doi.org/10.11646/zootaxa.4450.2.1

Blake, J.A., Maciolek, N.J. \& Meißner, K. (2017) 7.4.1 Family Spionidae Grube, 1850. Pp. 1-103, In: Purschke, G., Böggemann, M. \& Westheide, W. (Eds.), Handbook of Zoology. Annelida. Volume 2: Annelida Basal groups and Pleistoannelida, Sedentaria II. $i-i x, 1-465$. De Gruyter, Berlin. [On line edition] https://doi.org/10.1515/9783110291681-001

Duperron, S., Halary, S., Lorion, J.,Sibuet, M. \& Gaill, F. (2008) Unexpected co-occurrence of 6 bacterial symbionts in the gill of the cold seep mussel Idas sp. (Bivalvia: Mytilidae). Environmental Microbiology, 10, 433-445. https://doi.org/10.1111/j.1462-2920.2007.01465.x

Gofas, S. (2005) Geographical differentiation in Clelandella (Gastropoda: Trochidae) in the northeastern Atlantic. Journal of Molluscan Studies, 71, 133-144. https://doi.org/10.1093/mollus/eyi016

Grube, AE. (1850) Die Familien der Anneliden. Archiv für Naturgeschichte, Berlin, 16, 249-364. [https://biodiversitylibrary. org/page/32498980]

Laubier, L. \& Ramos, J. (1974) Polydora guillei sp. nov. nouvelle espèce de Polychète spionidien en Méditerranée occidentale. Vie et Milieu, 24 (3A), 479-486. [https://wwwphp.obs-banyuls.fr/Viemilieu/images/Archives_1950-2002/vie-et-milieu/ VOLUME_1974_24_fasc3_A.pdf]

Lykousis, V., Alexandri, S., Woodside, J., de Lange, G., Dählmann, A., C. Perissoratis, C., Heeschen, K., Ioakim, Chr., Sakellariou, D., Nomikou, P., Rousakis, G., Casas, D., Ballas, D. \& Ercilla, G (2009) Mud volcanoes and gas hydrates in the Anaximander mountains (Eastern Mediterranean Sea). Marine and Petroleum Geology, 26, 854-872. https://doi.org/10.1016/j.marpetgeo.2008.05.002

Mackie, A.S.Y. \& Duff, A.L. (1986) Atherospio disticha gen. et sp. nov. (Polychaeta: Spionidae) from Loch Tuirnaig, west coast of Scotland. Ophelia, 25, 139-146. https://doi.org/10.1080/00785326.1986.10429745

Maciolek, N.J. (1985) A revision of the genus Prionospio Malmgren, with special emphasis on species from the Atlantic Ocean, and new records of species belonging to the genera Apoprionospio Foster and Paraprionospio Caullery (Polychaeta, Annelida, Spionidae). Zoological Journal of the Linnean Society, 84, 325-383. https://doi.org/10.1111/j.1096-3642.1985.tb01804.x

Meißner, K. \& Bick, A. (2005) Atherospio guillei (Laubier \& Ramos, 1974) comb. nov. (Polychaeta: Spionidae) and closest relatives. Zoologischer Anzeiger, 244, 115-123. https://doi.org/10.1016/j.jcz.2005.07.001

Murtey, M.D. \& Ramasamy, P. (2016) Sample Preparations for Scanning Electron Microscopy. In: Janecek, M. \& Kral, R. (Eds.), Modern Electron Microscopy in Physical and Life Sciences. IntechOpen, London, pp. 161-185. https://doi.org/10.5772/61720 
Olu-Le Roy, K., Sibuet, M., Fiala-Medioni, A., Gofas, S., Salas, C., Mariotti, A., Foucher, J.-P. \& Woodside, J. (2004) Cold seep communities in the deep eastern Mediterranean Sea: composition, symbiosis and spatial distribution on mud volcanoes. Deep-Sea Research I, 51, 1915-1936. https://doi.org/10.1016/j.dsr.2004.07.004

Perissoratis, C., Ioakim, Chr., Alexandri, S., Woodside, J., Nomikou, P., Dählmann, A.D., Casas, D., Heeschen, K., Amman, H., Rousakis, G. \& Lykousis V. (2011) Thessaloniki Mud Volcano, the Shallowest Gas Hydrate-Bearing Mud Volcano in the Anaximander Mountains, Eastern Mediterranean. Journal of Geological Research, 2011, Article 247983, 1-11. https://doi.org/10.1155/2011/247983

Raineault, N.A., Ramey-Balci, P.A., Shank, T.M., Bors, E., Duman, M., Ürkmez, D. \& Tüzün, S. (2013) Exploration of the Anaximander Mountains: Mud Volcanoes, Cold-Seep Communities, and Cold Water Corals, Pp. 30-35. In: Bell, K.L.C. \& Brennan, M.L. (Eds.), New frontiers in ocean exploration: The E/V Nautilus 2012 field season and summary of Mediterranean exploration. Oceanography, 26 (1), supplement, 64 pp. https://doi.org/10.5670/oceanog.2013.supplement.01

Reuscher, M.G. \& Fiege, D. (2016) Ampharetidae (Annelida: Polychaeta) from cold seeps off Pakistan and hydrothermal vents off Taiwan, with the description of three new species. Zootaxa, 4139 (2), 197-208. https://doi.org/10.11646/zootaxa.4139.2.4

Southward, E.C., Andersen, A.C. \& Hourdez, S. (2011) Lamellibrachia anaximandri n. sp., a new vestimentiferan tubeworm (Annelida) from the Mediterranean, with notes on frenulate tubeworms from the same habitat. Zoosystema, 33 (3), 245 279. https://doi.org/10.5252/z2011n3a1

Sturany, R. (1896) Zoologische Ergebnisse VII. Mollusken I (Prosobranchier und Opisthobranchier; Scaphopoden; Lamellibranchier) gesammelt von S.M. Schiff "Pola" 1890-1894. Denkschriften der Kaiserlichen Akademie der Wissenschaften, Mathematische-Naturwissenschaftischen Classe, 63, 1-36, pl.1-2.

Taviani, M. (2014) Chemosynthesis in the Mediterranean Sea. Pp: 69-83. In: Goffredo, S. \& Dubinsky, Z. (Eds.), The Mediterranean Sea: Its history and present challenges, Springer, Dordrecht, pp. 69-83. https://doi.org/10.1007/978-94-007-6704-1_5 